\title{
Reconstruction of past climatic events using oxygen isotopes in Washingtonia robusta growing in three anthropic oases in Baja California Sur
}

\author{
Andrea Martínez-Ballesté, Exequiel Ezcurra
}

\begin{abstract}
Andrea Martínez-Ballesté
andrea.martinez@ib.unam.mx

Instituto de Biología-Jardín Botánico, Universidad Nacional Autónoma de México, Av. Universidad 3000, Ciudad Universitaria, Coyoacán, C.P. 04510, Cd. Mx., México.
\end{abstract}

\section{Exequiel Ezcurra}

UG-MEXUS, University of California-Riverside, 3324 Olmsted Hall Riverside, CA 92521, USA.

BOL. SOC. GEOL. MEX. 2018

VOL. 70 NO. 1

P. $79-94$

http://dx.doi.org/10.18268/BSGM2018v70n1a5

Manuscript received: December 14, 2016 Corrected manuscript received: June 24, 2017 Manuscript accepted: August 29, 2017

\begin{abstract}
The term Anthropocene has been suggested to describe the epoch in which changes in Earth systems can be clearly attributable to human activities. The oasis ecosystems of the Baja California Peninsula provide a good example of the transformations that human activities can produce in an ecosystem over centuries of use. These sites, which are located in the northwestern desert of Mexico, are a refuge for a great diversity of species. At the same time, they are important for human subsistence, which has exerted pressure on the water resources of these ecosystems since humans settled in these locations following the arrival on the American continent. To reconstruct the changes in hydrological conditions in these ecosystems and their relationship with climatic patterns and human activities during the last century, we measured $\delta^{18} \mathrm{O}$ isotopes in the stem cellulose of the longlived palm Washingtonia robusta in three Baja California Sur oases. Samples were collected at different heights from the base to the top (i.e., from the oldest part of the stem to the youngest of each palm and from different water sources. The oxygen isotope values of $W$. robusta appear to be influenced mainly by intense climatic anomalies. Some El Niño Southern Oscillation (ENSO) events were recorded in the isotope signals of the palms, such as La Niña drought event that occurred between 1942 and 1957 and caused an evident increase in the $\delta^{18} \mathrm{O}$ of the palms of the San Ignacio oasis. However, other ENSO events did not produce isotope changes in the palms.

We propose that the hydrological characteristics of the oases, as well as agricultural irrigation, likely maintained constant moisture conditions that caused the observed stability of the ${ }^{18} \mathrm{O} /{ }^{16} \mathrm{O}$ isotope ratios in the palms and limited the evidence of climatic anomalies that these palms provide. Although W. robusta can serve as a reasonable proxy for climate reconstructions, improvements in our understanding are needed; e.g., more accurate methods for estimating the ages of palms and more knowledge of the effects of other factors related to the hydrological cycles of oases.
\end{abstract}

Keywords: oxygen isotopes, oasis, Baja California, ENSO, palm, climatic anomalies.

\section{RESUMEN}

El término Antropoceno ha sido propuesto para describir la época en que los cambios en sistemas terrestres pueden ser claramente atribuibles a las actividades humanas. Los oasis de la península de Baja California son un buen ejemplo de las transformaciones que las actividades humanas pueden producir en un ecosistema durante un largo período de tiempo. Estos sitios, ubicados en el desierto del noroeste de México, son refugio para una gran diversidad de especies. Al mismo tiempo, son importantes para la subsistencia humana, que ha ejercido presión sobre los recursos hídricos de estos ecosistemas desde que los humanos se establecieron en estos lugares después de su llegada al continente Americano. Para reconstruir los cambios hidrológicos en estos ecosistemas y su relación con los patrones climáticos y las actividades humanas durante el último siglo, medimos los isótopos de $\delta^{18} \mathrm{O}$ en la celulosa del tallo de las palmas de vida larga, Washingtonia robusta, en tres oasis de Baja California Sur. Las muestras de madera se colectaron a diferentes alturas desde la base hasta la parte superior (es decir, desde la parte más antigua del tallo hasta la parte más joven del mismo) de cada palma y también se obtuvieron muestras de agua de diferentes fuentes presentes en los sitios de estudio. Los valores de isótopos de oxígeno de W. robusta parecen estar influidos principalmente por anomalías climáticas intensas. Algunos eventos de El Niño (El Niño Southern Oscillation, ENSO) fueron registrados en las señales isotópicas de las palmas, así como un evento de La Niña que ocurrió entre 1942 y 1957 y causó un aumento evidente en los isótopos $\delta^{18} \mathrm{O}$ de las palmas del oasis de San Ignacio. Sin embargo, otros eventos ENSO no produjeron cambios isotópicos en las palmas. Proponemos que la infraestructura hidráulica de los oasis incluido el riego agrícola, posiblemente mantuvo condiciones de humedad constantes que causaron una estabilidad en la proporción de isótopos ${ }^{18} \mathrm{O} /{ }^{16} \mathrm{O}$ en las palmas y limitaron la evidencia isotópica de las anomalías climáticas en la celulosa de las palmas. Aunque la evidencia isotópica de $\underline{W}$. robusta puede ser utilizada como una aproximación razonable para las reconstrucciones climáticas, se necesita encontrar métodos más precisos para estimar la edad de las palmas y un conocimiento más cercano de otros factores relacionados con los ciclos hidrológicos de los oasis.

Palabras clave: isótopos de oxígeno, oasis, Baja California, ENSO, palma, anomalías climáticas. 


\section{Introduction}

Due to the magnitude of the impacts that human transformations have produced in the Earth system, the current geological epoch is referred to as the Anthropocene (Crutzen, 2006; Ehlers and Krafft, 2006; Mauser, 2006). The oasis ecosystems of the Baja California peninsula are good examples of the changes that human activities can produce in an ecosystem. These sites, which are located in the northwestern desert of Mexico, are a refuge for a great diversity of native species of mesic affinity and some species that are characteristic of the surrounding xerophilous scrub (Arriaga and Estrella, 1997). Many amphibians, reptiles, and mammals (Álvarez et al., 1997a, 1997b) inhabit these locations, and many migratory bird species visit them (Rodriguez-Estrella et al., 1997). In total, 184 oases have been recorded in the Baja California peninsula, 171 of which are in Baja California Sur (Maya et al., 1997). Human activities have affected the oases of Baja California since humans arrived on the American continent (Cariño, 1996). The first inhabitants of Baja California used these oasis ecosystems intermittently to obtain water and some fruits, in addition to other resources extracted from the desert and ocean (Jordán, 2005). Later, after the arrival of the Jesuits in Baja California in the seventeenth century, the availability of permanent or intermittent bodies of water allowed the establishment of missions; subsequently, permanent populations settled in the oases (Del Barco et al., 1988). Currently, the oases of Baja California preserve many native species, as well as introduced species that the missionaries brought to the new world and became part of the local markets.

As in other desert regions, the frequency of rain pulses is a critical factor in the maintenance and subsistence of arid areas in northwestern Mexico (Caso et al., 2007). The rainfall patterns in these areas are characterized by long periods of drought followed by short periods of intense rain. These rains are critical for the reproduction, establishment, and survival of biotic populations (Caso et al., 2007).

Pulse-type rain in desert environments has been related to global periodic atmospheric changes and ocean streams (Los et al., 2001), particularly the phenomenon known as the El Niño Southern Oscillation (ENSO). ENSO results from temperature changes at the ocean surface and manifests as periodic climatic anomalies that cause marked changes in rainfall in the coastal deserts of North and South America (Barber and Chavez, 1983; Holmgren and Scheffer, 2001; Holmgren et al., 2016).

It has been suggested that the ENSO-related rainfall pattern varies along the Pacific coast of Mexico Mexican Pacific. The El Niño events tend to increase rainfall in the northwestern part of Mexico above $22^{\circ} \mathrm{N}$ latitude, which includes the entire Baja California peninsula; however, these events produce drought in the South Pacific Ocean. In contrast, the La Niña phenomenon produces drought in northwest Mexico and rains in the South Pacific Ocean (Caso et al., 2007).

Some authors have suggested that the rains that occur during the summer monsoon period are the main source of water to the water-bearing oases of Baja California Sur, followed by late summer Pacific hurricanes and tropical storms (Caso et al., 2007; Wurl et al., 2013) to maintain biodiversity and support human subsistence. Both periodic floods and droughts regulate the structure and composition of the plant communities in the oases (León de la Luz et al., 1997) and have been related to historical land use and the development of different economic activities in the oases (Cariño, 1996; Martínez-Ballesté, 2014).

The isotope ratios in plant tissue can be used to reconstruct past environmental changes and their relationship with regional and global hydrological processes (Santiago et al., 2005). In addition, these ratios have been used to obtain information on the environmental conditions during plant growth that are associated with plant metabolic and physiological responses (English et al., 2007). Recent studies in this field have substantially improved the accuracy of estimating past hydrologic 
changes through measuring the isotope signals of $\delta^{18} \mathrm{O}, \delta \mathrm{H}$, and $\delta^{13} \mathrm{C}$ and ${ }^{14} \mathrm{C}$ in plants (Roden et al., 2000; Sternberg et al., 2003; English et al., 2007). Oxygen isotopes are used to determine the sources of the water contained in the xylem of trees. Such reconstructions are possible because isotope fractionation does not occur during the process of root absorption (Reyes-García and Andrade, 2007), and changes in isotope values during the formation of cellulose can be evaluated. The cellulose found in the growth rings of trees has been used to reconstruct past climate conditions, specifically precipitation and temperature; however, few studies have reconstructed past climates from species lacking secondary growth (Desantis et al., 2007; English et al., 2007).

Monocotyledons are flowering plants whose seeds typically contain only one embryonic leaf or cotyledon. These plants lack a vascular cambium and thus do not have secondary growth that increases the plant diameter (Uhl and Dransfield, 1987). Palms are recognized as monocotyledonous species. Although the growth of their stems cannot be calculated using concentric rings, as in species with lateral meristems, it can be measured vertically at different heights. The younger part of a palm is found at the top of the palm, whereas the oldest part is found at the base.

In the oases of Baja California Sur, the palm Washingtonia robusta $(\mathrm{H}$. Wendl.) is one of the most abundant riparian vegetation species, and it is native to this ecosystem. It has been suggested that W. robusta can live for more than 500 years (Bullock and Heath, 2006). Therefore, this species may represent a useful proxy for reconstructing past climate events and can provide evidence of environmental changes, particularly in oasis ecosystems that currently lack suitable proxies for climate reconstruction.

In this research, we measured the $\delta^{18} \mathrm{O}$ stable isotope composition in the stem of the long-lived palm Washingtonia robusta, which is common in the oases of Baja California Sur, to determine whether the $\delta^{18} \mathrm{O}$ signal at different stem heights reflects historical changes in both precipitation and temperature. We expected to find impoverishment in ${ }^{18} \mathrm{O}$ (the heavy isotope) and enrichment in ${ }^{16} \mathrm{O}$ (the light isotope) during periods of relatively high rainfall and the opposite pattern (i.e., ${ }^{18} \mathrm{O}$ enrichment and ${ }^{16} \mathrm{O}$ impoverishment) under conditions including relatively high temperatures (Reyes-García and Andrade, 2007). Our research questions were as follows: Can the $\delta^{18} \mathrm{O}$ curves of the palm $W$. robusta be used as a proxy to describe historical changes in rainfall and temperature patterns in oases? Are the $\delta^{18} \mathrm{O}$ values sensitive to periodic climatic events such as ENSO and to human activities in these ecosystems?

\section{Methods}

\subsection{STUDY SITE AND FIELDWORK}

This research was conducted in 2009 in the Mulegé, San Ignacio, and San Jose de Comondú oases in northern Baja California Sur, Mexico (Figure 1). Permanent human populations live in these locations, and these populations depend on agriculture and livestock maintained by irrigation systems developed by the Jesuits in the seventeenth century. In the twentieth century, the tourism industry developed in some of these oases, particularly the Mulegé and San Ignacio oases.

We selected four to six palms in each oasis and samples were collected from the stem core of each palm at one-meter intervals, starting at the palm base and ending at the top, where the first green leaves begin to grow.

We were unable to identify a suitable method for estimating palm age because the literature does not report any reliable method, except for the measurement of ${ }^{14} \mathrm{C}$, however we did not have the resources to perform that analysis. For this reason, we decided to ask local residents for this information. The ages of the palms at San Ignacio was estimated based on their observation and memories of the size and age of the palms in his childhood and then adding the years that have passed since then, however, in the other two locations we could 


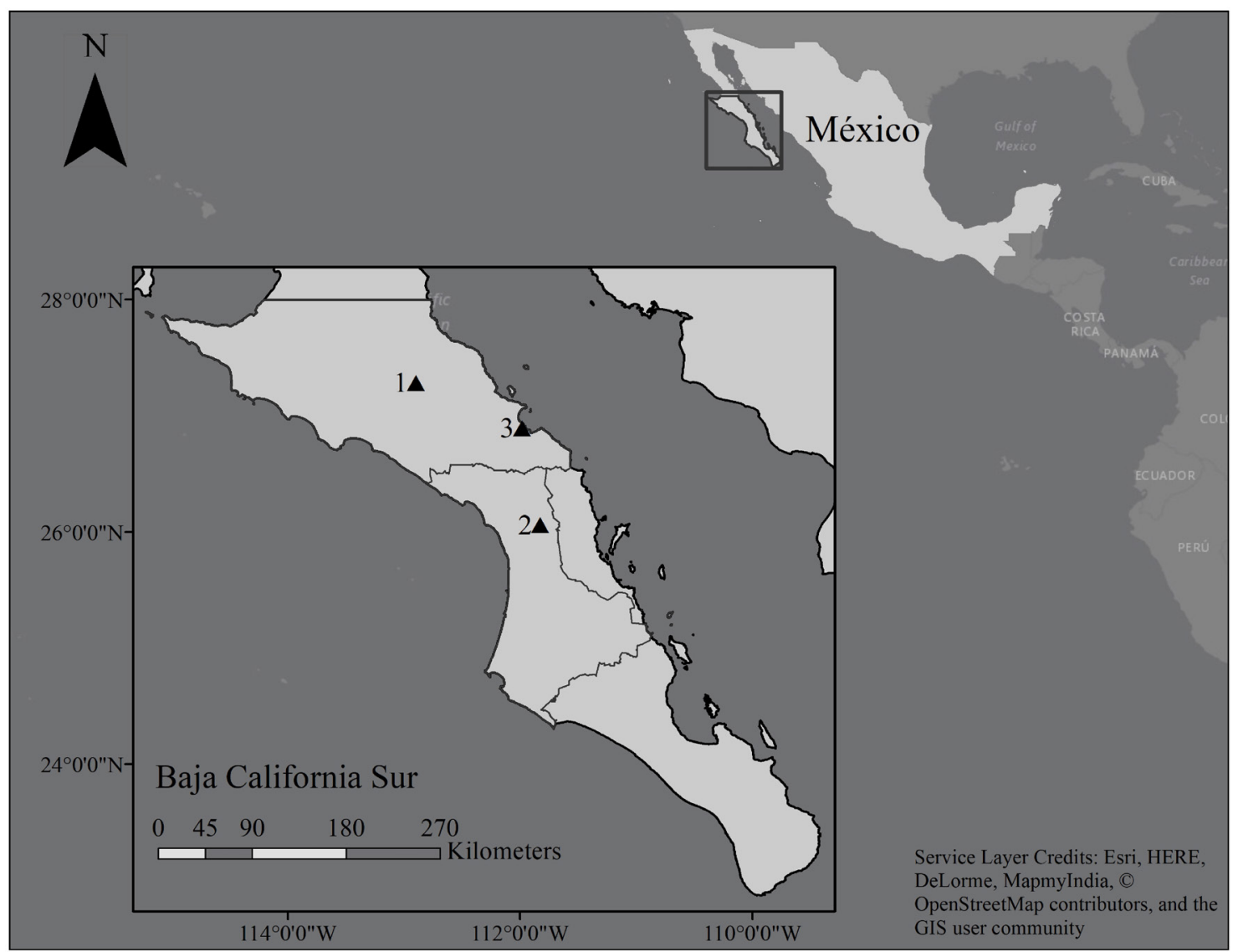

Figure 1 Location of study sites in the state of Baja California Sur; San Ignacio oasis (1), San José de Comondú oasis (2), and Mulegé oasis (3).

not obtain this information and the people just showed us the palms that they considered were the oldest or the highest.

It is known that the growth rate of palms can change greatly, depending on the environmental conditions in which they develop (Pulido and Caballero, 2006; Martínez-Ballesté et al., 2008; Macedo et al., 2016) and it is possible that for this cause the ages of the palms estimated in San Ignacio was quite variable in relation to the height of the palms (see Table 1). Was for this reason that we decided not to use the information of San Ignacio to infer the ages of the palms found in the other two localities. Given that we selected only the palms that were tallest or oldest, as reported by the locals, we assumed that all of the palms in Mulegé and Comondú oases were approximately 70 yr. old, which was the maximum age of the San
Ignacio palms.

To determine the sources of water used by the palms, water was collected from all possible origins in each oasis. These potential sources included rainwater, irrigation ditches, fluvial sources, wells, and edaphic sources, as well as the ocean. In total, thirteen water samples were collected from different sources among the three oases.

The palms grew close to water-bearing locations intended for orchards. Historically, these orchards contained various crops, including date palm, sugarcane, vines, vegetables, and fruit trees; however, the diversity of orchard crops in these three oases is currently low.

\subsection{SAMPLE PREPARATION AND LABORATORY ANALYSIS}

The stem samples collected in the field were dried 
Table 1. Heights of the sampled palms in the three oases and the ages estimated by local people in the oasis of San Ignacio. The values enclosed in parentheses represent the upper portions of the palms that we could not sample, due to the dry leaves that cover the stem.

\begin{tabular}{|c|c|c|c|}
\hline Oases & Palm & $\begin{array}{l}\text { Total height } \\
\text { (m) }\end{array}$ & $\begin{array}{c}\text { Age estimated } \\
\text { by locals (yr) }\end{array}$ \\
\hline \multirow[t]{6}{*}{ Comondú } & 1 & $16(-3)$ & $\mathrm{NC}$ \\
\hline & 2 & $18(-3)$ & $\mathrm{NC}$ \\
\hline & 3 & $14(-2.5)$ & $\mathrm{NC}$ \\
\hline & 4 & 13.6 & $\mathrm{NC}$ \\
\hline & 5 & $14.6(-2.3)$ & $\mathrm{NC}$ \\
\hline & 6 & $15.1(-3)$ & $\mathrm{NC}$ \\
\hline \multirow[t]{4}{*}{ Mulegé } & 1 & 14 & $\mathrm{NC}$ \\
\hline & 2 & 12.2 & $\mathrm{NC}$ \\
\hline & 3 & 16.7 & $\mathrm{NC}$ \\
\hline & 4 & 14.7 & $\mathrm{NC}$ \\
\hline \multirow[t]{6}{*}{ San Ignacio } & 1 & 13 & 40 \\
\hline & 2 & 14 & 40 \\
\hline & 3 & $10.7(-2)$ & 70 \\
\hline & 4 & $10.4(-2)$ & 70 \\
\hline & 5 & $16(-3)$ & 60 \\
\hline & 6 & $15(-3)$ & 60 \\
\hline
\end{tabular}

NC, not calculated

at $65^{\circ} \mathrm{C}$ for three days. Subsequently, small pieces of the central part of each of the collected stems were separated using knives; each piece contained xylem vessels and parenchyma. At the laboratory at the Department of Botany and Plant Sciences, University of California, Riverside, the stem samples were milled and homogenized in a centrifugal mill (8000 D Mixer/Mill, SamplePrep SPEX, Metuchen, NJ, USA) and then dried overnight in $20 \mathrm{ml}$ vials at $50^{\circ} \mathrm{C}$. To perform the oxygen isotope analyses, the milled samples were weighed in silver foil cups; each sample had an approximate weight of 0.8 to $1.2 \mathrm{mg}$. A total of 204 collected stem samples and 13 water samples from different sources were sent to the Facility for Isotope Ratio Mass Spectrometry at the University of California, Davis, for oxygen isotope $\left(\delta^{18} \mathrm{O}\right)$ analysis.

\subsection{DATA ANALYSIS}

\subsection{1. $\delta^{18} O$ VALUES AT DIFFERENT HEIGHTS}

The $\delta^{18} \mathrm{O}$ values obtained from samples of $W$. robusta at different heights were analyzed via regres- sion to obtain the residuals, which were plotted as an isotope curve for each of the palms sampled. The $\delta^{18} \mathrm{O}$ series of each individual were detrended by estimating a linear regression of isotopic values as a function of palm tree height, and assigning the regression residual to each height. This transformation was performed to eliminate potential bias produced by any trend in the isotopic values along the height of the observed individual. Thus, isotopic anomalies would be directly comparable with climatic anomalies.

\subsubsection{ANALYSIS OF DATA FROM METEOROLOGICAL TIME SERIES}

Historical rain and temperature data were requested to the National Meteorological System of the National Water Commission. The meteorological data series of Mulegé covers the period between 1922 and 2010, whereas those of Comondú and San Ignacio begin in 1938 and 1939, respectively, and both end in 2010. The trends in precipitation and annual temperature were obtained as follows: The annual rainfall and maximum temperature 
data were modified by removing the long-term trends (which are relatively weak) and magnifying the short-term trends (which are more intense). The number of observations was reduced to 48 over a 4-year interval by calculating the moving average for both precipitation and temperature. This procedure was followed to relate the sparse palm isotope data to the many meteorological data on a comparable scale. By removing the scale differences in the data, the general tendency was obtained, and the climatic anomalies were graphed. We did not use the database of minimum temperatures for two reasons: First, these oases never experienced temperatures below $0{ }^{\circ} \mathrm{C}$. Second, the maximum temperatures lead to greater degrees of fractionation of ${ }^{18} \mathrm{O} /{ }^{16} \mathrm{O}$ than the minimum temperatures.

\subsubsection{MATCHING THE $\delta^{18}$ O CURVES WITH WEATHER ANOMALIES}

Using the estimated palm ages, we adjusted their isotope curves to the graphs of the time series recorded for the precipitation and maximum temperature anomalies. Due to the presence of a thick layer of dry leaves at the upper parts of the palm stems, we were not always able to obtain samples all the way to the top (Table 1). In these cases, we subtracted the number of recent years for which we did not have data and adjusted the isotope curves to a date in the past that we had calculated. This procedure was carried out using the total palm height, the height at which the uppermost sample was taken, and the palm age.

Once the isotope curves had been adjusted to the time series of the climatic events, we used dotted vertical lines in the adjusted graphs to identify the points at which the ${ }^{18} \mathrm{O} /{ }^{16} \mathrm{O}$ ratios of the isotope curves showed clear increasing or decreasing trends related to the changes in precipitation and temperature. The heavier isotope ${ }^{18} \mathrm{O}$ becomes less abundant relative to the light isotope ${ }^{16} \mathrm{O}$ during periods of relatively high rainfall, whereas the opposite pattern $\left(\right.$ i.e., ${ }^{18} \mathrm{O}$ enrichment and ${ }^{16} \mathrm{O}$ impoverishment) is observed when relatively high temperatures occur (Reyes-García and Andrade, 2007)

\section{Results}

Some inflection points in the isotope curves matched or were close to pronounced climatic anomalies, but there was no evidence of the effect of climatic anomalies on the $\delta^{18} \mathrm{O}$ values in other parts of the curve. Only at the points highlighted with dotted vertical lines can we state that $\delta^{18} \mathrm{O}$ increases occurred due to decrease in precipitation and increase in temperature, or $\delta^{18} \mathrm{O}$ decreased when the precipitation increased and the temperature decreased (Figures 2, 3, and 4).

The average $\delta^{18} \mathrm{O}$ value of palm cellulose was 23.4 $\%$. The values of the water sources exhibited a gradient ranging from negative to positive from deeper water horizons to surface water. Water collected from wells had the most negative values, whereas those of surface water and rain were positive (Table 2).

Data obtained from the National Oceanic and Atmospheric Administration (NOAA) show the periodicity of El Niño/La Niña events since 1897 (Figure 5). Black bars show periods of La Niña events, and blanks correspond to years in which the El Niño event occurred. Within the period recorded by the $\delta^{18} \mathrm{O}$ curves in this research, a long drought (La Niña) event occurred from 1942 to 1957 in Baja California Sur. This event coincides with an increase of the $\delta^{18} \mathrm{O}$ values between 1950 and 1955 for 4 of the 6 isotope curves of the palms sampled at the San Ignacio oasis (Figure 2). The longest rainy period reported by the NOAA meteorological service occurred between 1978 and 1988; however, the $\delta^{18} \mathrm{O}$ values of the palms did not show an evident reduction at any of the sampled sites. Some other La Niña/El Niño events were associated with increases or decreases in $\delta^{18} \mathrm{O}$, as expected for these climatic events (Figures 2, 3, and 4).

The Mulegé oasis suffered considerable damage due to a flood that occurred in 1959 (Figure 6) that may have been related to an El Niño event in 1958 and high precipitation anomalies. This event was 

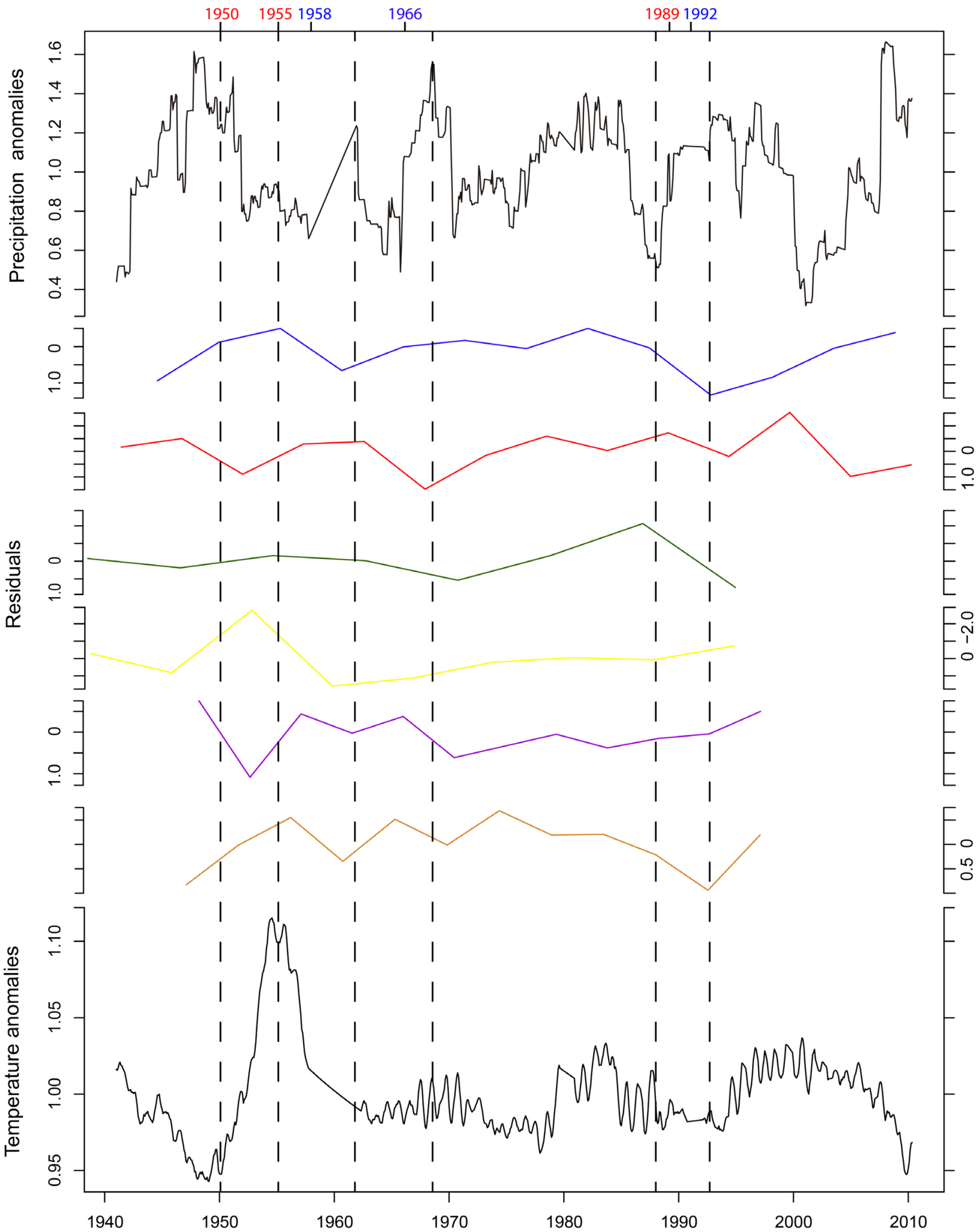

Figure 2 The relationship between the $\partial^{18} \mathrm{O}$ values of San Ignacio palms and climatic (precipitation and temperature) anomalies. The vertical dotted lines highlight the points where the residuals of all or almost all of the $\partial^{18} \mathrm{O}$ curves of the palms show similar patterns and coincide with the trends expected from the climatic anomalies. The red and blue colors show the La Niña and El Niño years, respectively, when the isotope curves coincide with droughts (La Niña) or wet periods (El Niño). 


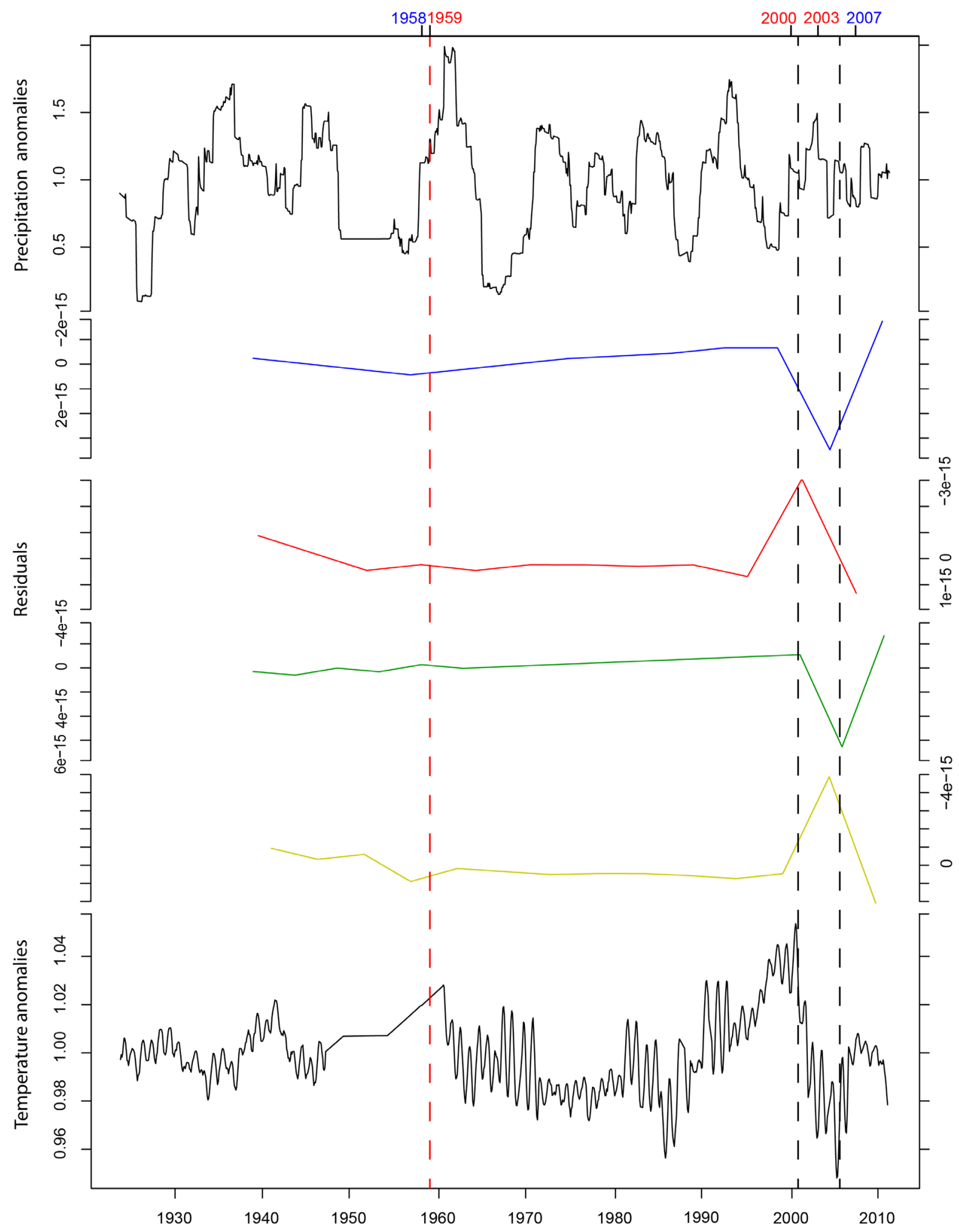

Figure 3 The relationship between the ${ }^{18} \mathrm{O}$ values of the Mulegé palms and climatic (precipitation and temperature) anomalies. The vertical dotted lines highlight the points where the residuals of all or almost all of the $\partial^{18} \mathrm{O}$ curves of the palms show similar patterns and coincide with the trends expected from the climatic anomalies. The red and blue colors show the La Niña and El Niño years, respectively, when the isotope curves coincide with droughts (La Niña) or wet periods (El Niño). The red vertical line marks the tropical storm that occurred in 1959 and that caused considerable flooding in the Mulegé oasis (observed in Figure 6). 

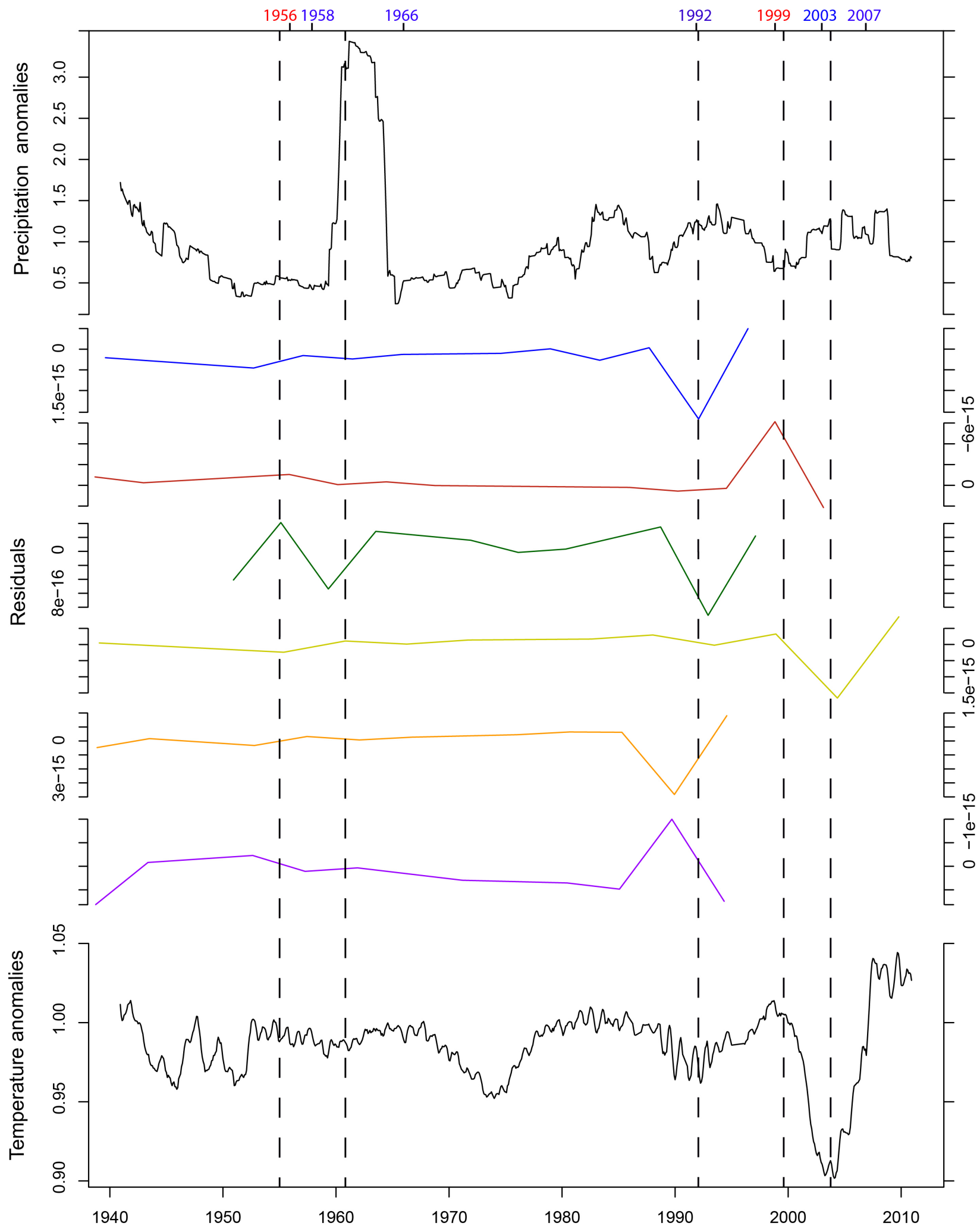

Figure 4 Matching the $\partial^{18} \mathrm{O}$ values of Comondú palms to precipitation and temperature climatic anomalies. The vertical dotted lines highlight the points where the residuals of all or almost all of the $\partial^{18} \mathrm{O}$ curves of the palms show similar patterns and coincide with the trends expected from the climatic anomalies. The red and blue colors show the La Niña and El Niño years, respectively, when the isotope curves coincide with droughts (La Niña) or wet periods (El Niño). 
Table 2. Location, origin and isotope values of water sources in three oases of Baja California Sur.

\begin{tabular}{|c|c|c|c|}
\hline Oases & Location & Origin of water & $\delta^{18} \mathrm{O}(\%)$ \\
\hline \multirow[t]{2}{*}{ Comondú } & $26^{\circ} 03.640^{\prime} \mathrm{N}, 111^{\circ} 49.393^{\prime} \mathrm{W}$ & \multirow{2}{*}{ Ditch } & -8.33 \\
\hline & $26^{\circ} 03.071^{\prime} \mathrm{N}, 111^{\circ} 49.860^{\prime} \mathrm{W}$ & & -7.56 \\
\hline \multirow[t]{5}{*}{ Mulegé } & $26^{\circ} 53.230^{\prime} \mathrm{N}, 111^{\circ} 59.161^{\prime} \mathrm{W}$ & Ditch & -6.28 \\
\hline & $26^{\circ} 53.194^{\prime} \mathrm{N}, 112^{\circ} 00.166^{\prime} \mathrm{W}$ & Edaphic & -5.76 \\
\hline & $26^{\circ} 53.765^{\prime} \mathrm{N}, 111^{\circ} 58.548^{\prime} \mathrm{W}$ & \multirow{2}{*}{ River } & -0.19 \\
\hline & $26^{\circ} 54.122^{\prime} \mathrm{N}, 111^{\circ} 57.587^{\prime} \mathrm{W}$ & & 0.73 \\
\hline & $26^{\circ} 54.250^{\prime} \mathrm{N}, 111^{\circ} 57.360^{\prime} \mathrm{W}$ & Ocean & 1.02 \\
\hline \multirow[t]{6}{*}{ San Ignacio } & $27^{\circ} 17.822^{\prime} \mathrm{N}, 112^{\circ} 53.940^{\prime} \mathrm{W}$ & \multirow{3}{*}{ Edaphic/Fluvial } & -3.65 \\
\hline & $27^{\circ} 17.899^{\prime} \mathrm{N}, 112^{\circ} 53.833^{\prime} \mathrm{W}$ & & -6.27 \\
\hline & $27^{\circ} 17.178^{\prime} \mathrm{N}, 112^{\circ} 54.251^{\prime} \mathrm{W}$ & & -4.26 \\
\hline & $27^{\circ} 17.104^{\prime} \mathrm{N}, 112^{\circ} 53.864^{\prime} \mathrm{W}$ & \multirow{2}{*}{ Ditch } & -5.73 \\
\hline & $27^{\circ} 17.097^{\prime} \mathrm{N}, 112^{\circ} 53.911^{\prime} \mathrm{W}$ & & -5.77 \\
\hline & & Rain & 3.54 \\
\hline
\end{tabular}




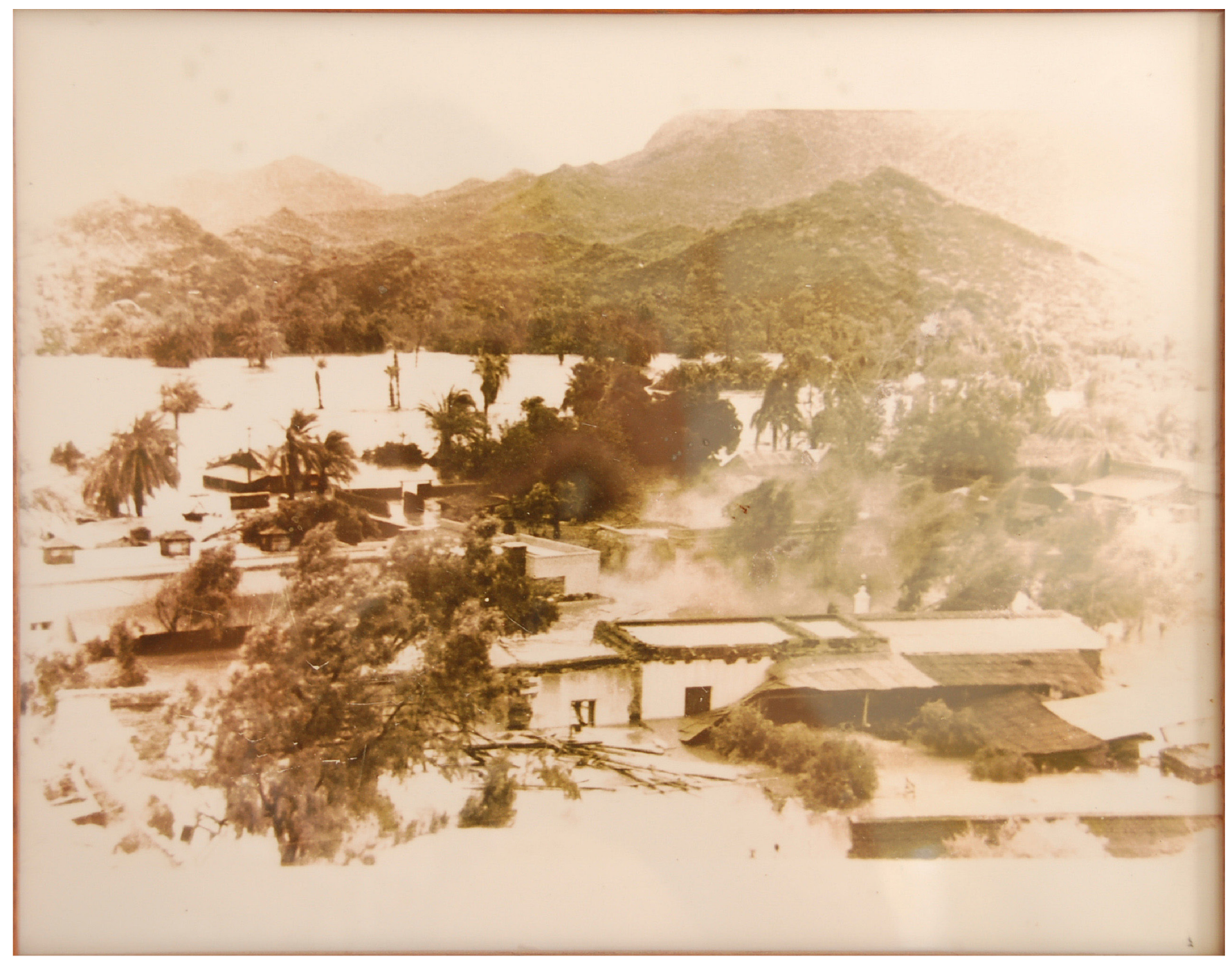

Figure 6 Flooding recorded in 1959 in the Mulegé oasis. Anonymous photographer.

recorded as a slight increase in the $\delta^{18} \mathrm{O}$ values in the isotope curves of the four palms sampled in this location (Figure 3).

\section{Discussion}

\subsection{HYDROLOGICAL DYNAMICS OF OASES AND AVAILABLE WATER SOURCES}

Water from surface sources in ecosystems is more enriched in ${ }^{18} \mathrm{O}$ than in ${ }^{16} \mathrm{O}$ because of fractionation during evaporation in the near-surface water horizons (Reyes-García and Andrade, 2007). In terms of our results, the positive values of $\delta^{18} \mathrm{O}$ measured in the $W$. robusta palm xylem suggest that the roots preferentially absorb water from sources that are enriched in ${ }^{18} \mathrm{O}$; i.e., irrigation ditches, rivers, and rain. The root behavior of $W$. robusta may be similar to that of other palms, such as Sabal palmetto, which have shallow roots that do not reach groundwater (Desantis et al., 2007). According to the hydrological regime of Baja California Sur, the groundwater deposits are mostly unconfined; only some are confined or semiconfined (Díaz and Troyo, 1997). This unconfined nature of the aquifers means that the water available to plants growing in the oases, including $W$. robusta palms, originates mainly from surface water sources. 


\subsection{ISOTOPE VALUES OF THE PALMS}

There is a direct correlation between the $\delta^{18} \mathrm{O}$ signals in the organic matter of the stems and the $\delta^{18} \mathrm{O}$ of rainwater because water absorbed by plants does not undergo isotope fractionation (White et al., 1985; Reyes-García and Andrade, 2007). In this sense, the isotope variations in $\delta^{18} \mathrm{O}$ in cellulose extracted from the $W$. robusta palms at different heights represent the historical climate-dependent levels of precipitation recorded at meteorological stations in the study region.

According to Reyes-García and Andrade (2007), when temperatures are high and the relative humidity is low, the organic matter forming during weather conditions will be less enriched in the heavy isotope ${ }^{18} \mathrm{O}$ and more enriched in the light isotope ${ }^{16} \mathrm{O}$. The opposite trend is noted when precipitation is high and temperatures are low. This behavior is evident at certain points within the isotope curves obtained for $W$. robusta, particularly in the years in which the changes in precipitation or temperature were more pronounced. That is, when precipitation and temperature anomalies increased or decreased markedly, the $\delta^{18} \mathrm{O}$ curves for most of the studied palms exhibited a direct proportional response to changes in temperature and an inverse response to changes in precipitation. When the temperature increased markedly and precipitation decreased, the palm cellulose forming at this moment became enriched in the heavier isotope $\left({ }^{18} \mathrm{O}\right)$ because the abundance of the light isotope $\left({ }^{16} \mathrm{O}\right)$ was reduced by evaporation; the opposite occurred with the contrasting climatic pattern.

In the San Ignacio oasis, well-defined inflection points were observed throughout the studied isotope curves for different palm heights within a period that we calculated as corresponding to 1939 to 2009. However, in the Comondú and Mulegé oases, inflection points were scarce, and most were observed for samples collected from the higher parts of the palm trees; i.e., in the most recently formed stem sections. Under constant moisture and temperature conditions, $\delta^{18} \mathrm{O}$ increases in both organic matter and water bodies until a stable isotope state is reached and the signal does not change (Flanagan et al., 1991). Although this state is not frequently achieved in natural environments (Harwood et al., 1999), the oases function as a very efficient hydraulic system, due to the relative abundance of water that accumulates in the springs, rivers, plains, and basins (Díaz and Troyo, 1997). For example, it is known that the springs that feed the Comondú oasis can provide water to the oasis ecosystem over many dry years and can also accumulate water in flood areas in the lower and upper parts of the basin, where it remains for months or even years (Wurl et al., 2013). Moreover, human activity has occurred in the studied oases for several centuries, and palms grow in orchards, where water is regularly supplied by irrigation. In the oases of Baja California, it is common to observe the presence of channels and gates for the distribution of water that were constructed by the Jesuits during the establishment of missions. Also, the construction of wells was promoted from 1950 (Ortega-Santos, 2013) to promote agriculture in the north of Baja California Sur. Thus, it is probable that the slight variation in the isotope curves compared to the climatic anomalies is the result of the hydrological characteristics of the system and of its anthropic management during the last century. A stable isotope state could have been reached in the water absorbed by the palm stems due to the irrigation water supply maintained under constant humidity levels, with little variation in the ${ }^{18} \mathrm{O} /{ }^{16} \mathrm{O}$ ratio. Therefore, only during climatic events of great intensity can we observe well-defined inflection points that indicate precipitation and temperature changes.

\subsection{RELATIONSHIP BETWEEN ISOTOPE BEHAVIOR AND ENSO EVENTS}

The rain pulses in the Baja California Peninsula related to ENSO increase during the El Niño phenomenon (Caso et al., 2007); and drought and temperature increases occur during La Niña years (Diaz et al., 2001). According to historical records from the NOAA meteorological system, several La 
Niña events that occurred between 1942 and 1957 could have caused a long period of drought in Baja California Sur, and a long period of relatively wet conditions occurred due to El Niño between 1978 and 1988. The data obtained from the meteorological stations reflect these events. However, only in San Ignacio did the isotope signal of all the studied palms increase in response to the considerable temperature increase that occurred from 1953 to 1957. There is evidence that in other species such as Pinus lagunae in Baja California Sur the long period of drought between 1939 and 1958 is observed in its growth rings (Diaz et al., 2001).

Although ENSO signal in tree rings in northern Mexico and the southern USA is strong and consistent (Stahle and Cleaveland 1993), the isotope values of $W$. robusta did not show notable changes during all ENSO events; only some ENSO periods were well marked at the defined points in figures 2 , 3 and 4. Specifically, the La Niña events of 1950, 1955, and 1989 and the El Niño events of 1958, 1966, and 1992 were recorded in the palms of the San Ignacio oasis; the La Niña events of 2000 and 2003 and the El Niño event of 2007 were recorded in the Mulegé oasis; and the La Niña events of 1956 and 1999 and the El Niño events of 1958, 1966, 1992, 2003, and 2007 were recorded in the Comondú oasis.

A picture taken in the Mulegé oasis shows the devastation caused by the heavy rainfall that occurred in 1959 (Figure 6). This strong rainfall event was considered along with other tropical storms as those that caused extensive damage in the region between 1957 and 2008 according to the registers presented by Wurl et al. (2013). As observed in the photograph, this storm caused considerable devastation in the town of Mulegé; however, only a small increase was observed in the $\delta^{18} \mathrm{O}$ of the palms.

\section{Conclusions}

The oxygen isotope values of $W$. robusta appear to be influenced by anomalous climate condi- tions; however, this influence was notable primarily when the intensities of the climatic anomalies were very large. In some cases, the most evident inflection points in the isotope curves were related to ENSO events, although this relationship was not always apparent. A prolonged drought event occurred between 1942 and 1957 due to periodic La Niña events, which caused an evident increase in $\delta^{18} \mathrm{O}$ of the palms of San Ignacio.

The isotope values of $W$. robusta were also influenced by the hydrological characteristics of the oasis ecosystem and human activity. The accumulation of water in springs that feed the oasis, and in irrigation systems used in agricultural activities, may have maintained a constant availability of moisture that may be related to the stability of the ${ }^{18} \mathrm{O} /{ }^{16} \mathrm{O}$ isotope ratios, which was observed as homogeneous isotope curves in which $\delta^{18} \mathrm{O}$ variations are not evident.

The isotope analysis of the water sources in the oasis showed that the palms mainly absorbed water from superficial sources, such as water moving through ditches and rivers; rain water was also absorbed directly. In this sense, the historical variations in groundwater cannot be reconstructed from the oxygen isotopes in $W$. robusta palm cellulose.

Although the isotope curves of $W$. robusta exhibited some relationship with historical climate events, the utility of the data might improve if a methodology to estimate the age of formation of stem cellulose were to be developed. Approaches for calculating the ages of plants using ${ }^{14} \mathrm{C}$ in species without growth rings, such as Pachycereus pringlei (Delgado-Fernández et al., 2016), Carnegiea gigantea (English et al., 2007), and tropical trees such as Otoba gracilipes and the palm Oenocarpus bataua (del Valle et al., 2014), have been developed. Similarly, it will be important for future research to calculate the relationship of the whole hydrological cycle, including precipitation, humidity, temperature, and evaporation that is involved in the absorption of water by $W$. robusta palms, to obtain more reliable assessments of $\delta^{18} \mathrm{O}$ in this species.

According to estimates based on increases in at- 
mospheric concentrations of $\mathrm{CO}^{2}$ driven by human consumption patterns, increases in temperature are expected, especially in the northern hemisphere. These temperature increases will likely be accompanied by increased droughts in arid and semi-arid zones. Similarly, the intensity and periodicity of extreme events, such as hurricanes, floods, tropical storms, and El Niño events, are expected to increase (Sauerborn and Matthies, 2006). In this respect, climatic reconstructions using isotopic data can be of great help in understanding the effects of the climatic scenarios estimated for a particular area, as well as the impact of human activities on the hydrological dynamics of species and the behavior of oasis ecosystems during the Anthropocene epoch.

\section{Acknowledgements}

The authors are grateful for the support provided by the National Council of Science and Technology (CONACyT) for the fellowship granted to the first author (Announcement I0010-2009-01, Request 000000000128785). The Center for Conservation Biology at the University of CaliforniaRiverside and particularly Dr. Mike Allen assisted in the development of this research. Dr. Lou Santiago, Dr. John Sickman, and Delores M. Lucero also supported the laboratory work and discussed this work with the authors. We appreciate the support of Dr. Pedro Peña and Dr. Carlos Martorell in the fieldwork. We are particularly grateful to Dr. Alexander Correa Metrio for his support in the statistical analysis presented in this study. Finally, we thank biologist Gonzalo Martinez Herrera for his help in producing Figures 1, 2, 3, and 4.

\section{References}

Álvarez, S.P., Galina, P., Arnaud, G., 1997a, Mamíferos, in Arriaga, L., RodríguezEstrella, R. (eds.), Los oasis de la Península de Baja California: La Paz, Baja California Sur, Centro de Investigaciones Biológicas del Noroeste, 249-259.

Álvarez, S.P., Galina, P., Grismer, L., 1997b, Anfibios y reptiles, in Arriaga, L., RodríguezEstrella, R. (eds.), Los oasis de la Península de Baja California: La Paz, Baja California Sur, Centro de Investigaciones Biológicas del Noroeste, 125-141.

Arriaga, L., Estrella, E., 1997, Los oasis de la Península de Baja California: La Paz, Baja California Sur, Centro de Investigaciones Biológicas del Noroeste, 292 p.

Barber, R.T., Chavez, F.P., 1983, Biological consequences of El Niño: Science, 222, 1203-1210.

Bullock, S.H., Heath, D., 2006, Growth rates and age of native palms in the Baja California desert: Journal of Arid Environments, 67, 391-402.

Cariño, M., 1996, Historia de las relaciones hombre-naturaleza en Baja California Sur, 1500-1940: La Paz, Baja California Sur, Universidad Nacional Autónoma de Baja California Sur, 229 p.

Caso, M., González-Abraham, C., Ezcurra, E., 2007, Divergent ecological effects of oceanographic anomalies on terrestrial ecosystems of the Mexican Pacific coast: Proceedings of the National Academy of Sciences of the United States of America (PNAS), 104, 10530-10535.

Crutzen, P.J., 2006, The Anthropocene, in Ehlers, E., Krafft, T. (eds.), Earth system science in the Anthropocene. Emerging issues and problems: Berlin, Springer-Verlag, 13-18.

Del Barco, M., Venegas, M., León-Portilla, M., 1988, Historia natural y crónica de la antigua California: adiciones y correcciones a la Noticia de Miguel Venegas: México, UNAM, Instituto de Investigaciones Históricas, 464 p.

Del Valle, J.I., Guarín, J.R. and Sierra, G.A., 2014, Unambiguous and low-cost determination of growth rates and ages of tropical trees and palms: Radiocarbon, 56, 39-52. 
Delgado-Fernández, M., Garcillán, P.P., Ezcurra, E., 2016, On the age and growth rate of giant cacti: Radiocarbon dating of the spines of cardon (Pachycereus Pringlei): Radiocarbon, $1-12$.

Desantis, L.R.G., Bhotika, S., Williams, K., Putz, F.E., 2007, Sea-level rise and drought interactions accelerate forest decline on the Gulf Coast of Florida, USA: Global Change Biology, 13, 2349-2360.

Diaz, S.C., Touchan, R., Swetnam, T.W., 2001, A tree-ring reconstruction of past precipitation for Baja California Sur, Mexico: International Journal of Climatology, 21, 1007-1019.

Díaz, S., Troyo, E., 1997, Balance hidrológico y análisis de la aridez, in Arriaga, L., RodríguezEstrella, R. (eds.), Los oasis de la Península de Baja California: La Paz, Baja California Sur, Centro de Investigaciones Biológicas del Noroeste, 35-50.

Ehlers, E., Krafft, T., 2006, Managing Global Change: Earth System Science in the Anthropocene, in Ehlers, E., Krafft, T. (eds.), Earth system science in the Anthtopocene. Emerging issues and problems: Berlin, Springer-Verlag, 5-12.

English, N.B., Dettman, D.L., Sandquist, D.R., Williams, D.G., 2007, Past climate changes and ecophysiological responses recorded in the isotope ratios of saguaro cactus spines: Oecologia, 154, 247-258.

Flanagan, L., Comstock, J.P., Ehleringer, J.R., 1991, Comparison of modeled and observed environmental influences on the stable oxygen and hydrogen isotope composition of leaf water in Phaseolus vulgaris L: Plant Physiology, 96, 588-596.

Harwood, K., Gillon, J., Roberts, A., Griffiths, H., 1999, Determinants of isotope coupling of $\mathrm{CO}^{2}$ and water vapor within a Quercus petraea forest canopy: Oecologia, 119, 109-119.

Holmgren, M., Stapp, P., Dickman, C.R., Gracia, C., Graham, S., Gutiérrez, J.R., Hice, C., Jaksic, F., Kelt, D.A., Letnic, M., Lima,
M., López, B.C., Meserve, P.L., Milstead, W.B., Polis, G.A., Previtali, M.A., Richter, M., Sabaté, S., Squeo, F.A., 2016, Extreme climatic events shape arid and semiarid ecosystems: Frontiers in Ecology and the Environment, 4, 87-95.

Holmgren, M., Scheffer, M., 2001, El Niño as a window of opportunity for the restoration of degraded arid ecosystems: Ecosystems, 4, 151-159.

Jordán, F., 2005, El Otro México: Biografia de Baja California: Tijuana, Universidad de Baja California, 398 p.

León de la Luz, J.L., Domínguez-Cadena, R., Domínguez-León, M., Pérez-Navarro, J.J., 1997, Floristic composition of the San José del Cabo oasis Baja California Sur, Mexico: SIDA, Contributions to Botany, 17, 599-614.

Los, S., Collatz, G., Bounoua, L., Sellers, P., Tucker, C., 2001, Global interannual variations in sea surface temperature and land surface vegetation, air temperature, and precipitation: Journal of Climate, 14, 1535-1549.

Martínez-Ballesté, A., Martorell, C., Caballero, J., 2008, The effect of Maya traditional harvesting on the leaf production, and demographic parameters of Sabal palm in the Yucatán Peninsula, Mexico: Forest Ecology and Management, 256, 1320-1324.

Martínez-Ballesté, A., 2014, Baja California oases: a historical description about their land use and natural resources, in Wehncke, E., Lara-Lara, J., Álvarez-Borrego, S., Ezcurra, E. (eds.), Conservation science in Mexico's Northwest Ecosystem status and trends in the Gulf of California: Riverside, UC Institute for Mexico and the United States (UCMEXUS), Secretaría de Medio Ambiente y Recursos Naturales (Semarnat), 299-310.

Macedo-Santana, F., Endress, B.A., López-Toledo, L., 2016, Palmilla: un importante recurso no maderable de Sonora: Biodiversitas, 125, 8-12. 
Mauser, W., 2006, Global change research, in Ehlers, E., Krafft, T. (eds.), Earth system science in the Anthropocene. Emerging Issues and problems: Berlin, Springer-Verlag, 3-4.

Maya, Y., Coria, R., Dominguez, R., 1997, Caracterización de los oasis, in Arriaga, L., Rodríguez-Estrella, R. (eds.), Los oasis de la Península de Baja California: La Paz, Baja California Sur, Centro de Investigaciones Biológicas del Noroeste, 5-25.

Ortega-Santos, A., 2013, Apogeo de La Identidad Oasiana (1890-1950), in Cariño, M., Breceda, A., Ortega-Santos, A., Castorena, L. (eds.), Evocando El Edén. Conocimiento, valoración y problemática del Oasis de los Comondú: Barcelona, Icaria editorial, S.A, 286-316.

Pulido, M.T., Caballero, J., 2006, The impact of shifting agriculture on the availability of Non-Timber orest Products: the example of Sabal yapa in the Maya lowlands of Mexico: Forest Ecology and Management, 222, 399-409.

Reyes-García, C., Andrade, J.L., 2007, Los isótopos estables del hidrógeno y el oxígeno en los estudios ecofisiológicos de plantas: Boletín de la Sociedad Botánica de México, 80, 19-28.

Roden, J.S., Lin, G., Ehleringer, J.R., 2000, A mechanistic model for interpretation of hydrogen and oxygen isotope ratios in treering cellulose: Geochimica et Cosmochimica Acta, 64, 21-35.

Rodriguez-Estrella, R., Rubio, L., Pineda, E., 1997, Los oasis como parches atractivos para las aves terrestres residentes invernantes, in Arriaga, L., Rodríguez-Estrella, R. (eds.), Los oasis de la Península de Baja California: La Sur, Baja California, Centro de Investigaciones Biológicas del Noroeste, 157-195.

Santiago, L.S., Silvera, K., Luis, J., Dawson, T.E., 2005, El uso de isotopos estables en biología tropical: Interciencia, 30, 536-542.

Sauerborn, R., Matthies, F., 2006, Global environmental change and human health, in Ehlers, E., Krafft, T. (eds.), Earth system science in the Anthropocene. Emerging Issues and problems: Berlin, Springer-Verlag, 113-134.

Stahle, D., Cleaveland, M., 1993, Southern Oscillation extremes reconstructed from tree rings of the Sierra Madre Occidental and southern Great Plains: Journal of Climate, 6, 129-140.

Sternberg, L., Anderson, W.T., Morrison, K., 2003, Separating soil and leaf water ${ }^{18} \mathrm{O}$ isotope signals in plant stem cellulose: Geochimica et Cosmochimica Acta, 67, 2561-2566.

Uhl, N., Dransfield, J., 1987, Genera Palmarum. A classification of palms based on the work of Harold E. Moore, Jr., London, Kew Royal Botanical Garden, 732 p.

White, J.W., Cook, E., Broecker, W., 1985, The $\mathrm{D} / \mathrm{H}$ ratios of sap in trees: Implications for water sources and tree ring $\mathrm{D} / \mathrm{H}$ ratios: Geochimica, Geochimica et Cosmochimica Acta, 49, 237-246.

Wurl, J., Martínez-García, C., Imaz-Lamadrid, M., 2013, Hidrología, in Cariño, M., Breceda, A., Ortega-Santos, A., Castorena, L. (eds.), Evocando El Edén. Conocimiento, valoración y problemática del Oasis de los Comondú: Barcelona, Icaria editorial, S.A, 89-105. 